\title{
Legal Status of Children Born Outside Marriage in Hindu Community of Bali (Human Rights Perspective)
}

\author{
Dr Ida Ayu Sadnyini, SH., MH. \\ Lecturer of Law Faculty Undiknas Denpasar
}

\begin{abstract}
Promiscuity will bring legal consequences for women and children to be born, if it does not accompanied by a legitimate marriage ceremony. The legal conscequences is about legal position or legal status of the child to be born. In general, under the prevailing legislation and awig awig of Pakraman Vilage, a child has only legal status and right of inheritance from his mother or his grandfather from the line of his mother. The problem that arises is, how was legal status of children born outside marriage under Balinese customary law? How was family responsibility towards the children born outside marriage in human right perspective? This legal research is included in empirical legal research, using primary and secondary data, with qualitative and argumentative descriptive analysis. Legal position of children born outside marriage is limited to inherit only from their mother. It is different from legitimate children whose full right of inheritance from their parent. Responsibility of the mother's familiy toward the child is until his/her death and obliged to perform pengabenan ceremony. The difference on inheritance right and social status of children born outside marriage is contratry to the Human Rights regulated in Article 28 B (2) UUD 1945 stating that every child has protection right over any kind of discrimination.
\end{abstract}

Keyword: legal status, children born outside marriage, Human Rights

\section{Introduction}

\subsection{Background}

Family law is generally caused by the presence of an incestuous relationship, but there are times when a blood relationship did not cause any legal kinship relation, as in the case of children born outside marriage of their parents. Children mentioned above do not have a legal relationship with their biological father. In contrary, not all legal relations of kinship are caused by blood relationship, as happened in the case of an adopted child (sentana peperasan). Adopted children in general do not always have a blood relationship, but sometimes adopted children have blood relations in the case of a child outside marriage is adopted by the father of their birth mother (grandparents), while the birth mother will have a status as his/her sister.

Adoption is a legal act. Legal actions cause people who previously did not have any kinship legal relations became legally related as a familly, similarly to relatinship between a biological child with his parents. Legal actions concerning adoption by his/her maternal (mother's family), solely for protecting human rights (HAM) of the child born outside marriage. So the child will have a status as a legitimate child. Article 28 B paragraph (2) of the Constitution 1945 states that every child has right to live, grow, and developed, and is entitled to protection from violence and discrimination [H. Soehino, 2013, Human Right, Development of Regulation and Implementation of Human Right in Indonesia, BPFE Yogyakarta, p.44]. So the difference in social treatment toward children outside marriage is a violation of human rights.

Family law relationship is also influenced by the kinship system embraced by a society. The Hindu community in Bali embraced patrilineal kinship system or fatherhood, better known by the Hindu community as kepurusa system or Purusa [Gde Panetje, 1989,Various notes of Balinese Customary Law, Publisher Guna Agung, Denpasar, p.23]. . Kepurusa system is a family system prioritizing lineage drawn from the lineage of the father. This will bring consequences on marriage or inheritance. Child outside marriage is included in the lineage of his mother's father (grandfather).

Family relationship [Ibid, p. 26] between the child and his (legitimately) unmarried mother is not different from the child's relationship with the mother of a legal marriage. Since family law of Hindu society in Bali is patrilineal, in case there is no legitimate biological father, thus in some purposes the child fall into the line of his/her mother's father, but not in all things, as for instance he will not automatically get inheritance from his grandfather. This condition lead to a distinction between legitimate children and children outside marriage, in addition to the term legitimate and illegitimate.

Children born outside legal marriage based on the results of the study, is cause by several factors [Ida Ayu Sadnyini, 2015, Women Marriage With Keris In bali In Three Dimension Appaches (Jurnal Internasional), IJSEA Internasional Journal of Software Engineering \& Applications Volume 1 Issu-7, October 2015, p. 198] such as pregnant women who is forbidden by her parents to marry her boyfriend, a pregnant woman abandoned by her boyfriend because her boyfriend had another woman, abandoned by her boyfriend because she had other male. Women who had more than one boyfried performing promiscuity until pregnant is included in moral decline or "moral crisis". Children born will not get recognition of their biological father, so that the child will be labeled as "illegitimate child" in Bali called bebinjat child. 


\section{International Journal of Science and Research (IJSR) \\ ISSN (Online): 2319-7064}

Index Copernicus Value (2013): 6.14 | Impact Factor (2015): 6.391

Since 1950 issues of modernity and promiscuity problems are two of important topics in discourse related to the image and the lives of women in Bali in the 1950s [I Nyoman Darma Putra, 2007, Balinese Woman of Old Era : Current perspective, Pustaka Larasan, Denpasar Bali, p. 61]. In the early days of independence, values of the West were widely impactful in Bali. It was evident in their lifestyle, clothing styles, and promiscuity among young people, especially the students. Conversations and concerns about the impact of modernization was increasingly discussed. Parents in villages were worried about the fate of their daughter. Moral crisis [Ibid, p. 63.] is used to express anxiety on the young women drawn in a stream of promiscuity and pregnancy outside marriage.

Promiscuity certainly involves men and women. Negative position is always directed towards women. The position of women in promiscuity could not be good enough, while the position of men has never been complained. Promiscuity bring consequences for women to be pregnant. Pregnancy has changed her body, her stomach enlarged day by day, in contrast to men, nothing appear as a result of his actions. That concequence become a catastrophe of women life. Their image in the society be changed from positive to negative. In Balinese terms is the change from "luhluwih" [ Luh luih means women who have respectable and horobale behavior, highly polite, whose words always make people happy, never lie, and never denounce others] to "luh luhu" [Luh luhu is the opposite of luh luih, including limitless interaction with some men, without considering the impacts]. Oh God, how cruel the society in assessing women. The majority of pregnant women is not due to their own fault, but due to the defected man, it also included as one of discriminations experienced by women. The statement above is a negative label to women.

Their actions and behavior will bring legal concequence on women and children to be born. The legal concequence is about inheritance rights of the child to be born. In general, under the prevailing legislation, and awig-awig of Pakraman Village, the child will only has the right of inheritance from his/her mother, if the mother has a legacy. However, in some cases, a child outside of marriage is abandoned by his mother and does not adopted by the grandfather. If the child outside marriage is raised by his grandfather, his/her legal status becomes clear in regard to the responsibility to nurture, educate, including Manusa yadnya [manusa yadnya ceremony is a ceremony held by adult until children, ngaben ceremony is commonly an obligation of a son/doughter to their parent, if the child was passed away first, the obligation comes to the parent. ] ceremony and cremation or ngaben ceremony.

Based on the description above, the writer is interested to use the title "Legal Status of Children Outside Marriage In Hindu community of Bali" (Human Rights Perspective).

\subsection{Formulation of problem.}

1) How is legal status of children outside marriage in Bali Customary Law?

2) How is responsibility towards the child outside marriage from Perspective of Human Rights?

\subsection{Research methods}

Type of research used is empirical legal research [Supasti Darmawan, 2005, Empirical Researh Method, without place of publisher, p.1], E. Jones call it as non doctrinal research [E. Jones, 1962, Cureent Trends in Legal Research, (Ekspert), Journal of Legal Education, p. 37]. The study was conducted directly to the location of the research including Denpasar, Buleleng and Tabanan to get the data of children outside of marriage. The necessary data is not quantitative, but a qualitative one [Lexy J.Moleong, 1990, Qualitative Research Methodology, Tarsito Bandung, p. 2.]. The collection of legal materials [Soerjono Soekanto and Sri Mamuji, 1990, Normative Legal Research :A Short Review, CV, Rajawali, Jakarta, p. 14] by using a card system stored in an laptop and documentation by taking pictures of ngaben [Ngaben is a ceremony of corps burning for Hindus in Bali, this ceremony can be held greatly with hundreads of million and also can be held simply by three million to fulfill the obligation and responsibility of ngaben] ceremony of a child outside of marriage. Primary data were collected by in-depth interviews with family and elite indigenous people called elite interviewing [Tjok Putra Astiti, 1994, Infuence of Customary Law and Plannrd Family Program toward changing values of doughter and son in the Community of Bali (Disertation). Postgraduate Program Institut Pertanian Bogor, p.58]. Researchers also participated in the pengabenan ceremony called involved direct observation [Sugiono, 2008, Understanding Qualitative Research Equipped with example of Research proposal and Report, Publisher Alpabeta, p. 64]. Analyses were performed with qualitative descriptive analysis as well as argumentative.

\section{Discussion}

\subsection{Legal Status of Children Outside Marriage In Bali Customary Law}

\section{A. Legal Status of Children Outside Marriage Based on Constitution}

Legal position of a child pursuant to Act No. 1 of 1974 Article 42 says, legitimate child is a child born in or as a result of a legal marriage. Article 43 paragraph (1) says a child born outside marriage has only a civil relationship with his/her mother. Position the child in paragraph (1) above will further be regulated in a government regulation.

Article 43 paragraph (1) above give rise to legal uncertainty for marital status and the status of children born. Illegitimate marriage cannot be registered in the Civil Registry Office. Status of children born of illegitimate marriage would be contrary to Article 28B paragraph (1) which says, "Everyone has the right to form a family and continue descent through legal marriage. Article 28B paragraph (2) states, "Every child has the right to live, grow, and develop as well as the right for protection from violence and discrimination" and Article 28D (1) says that, "Everyone has the right for recognition, security, protection and legal certainty and equal treatment before the law".

Based on the articles above, there should be no discrimination in the application of the law toward every body due to different ways of marriage. Children born of the 


\section{International Journal of Science and Research (IJSR) \\ ISSN (Online): 2319-7064}

Index Copernicus Value (2013): 6.14 | Impact Factor (2015): 6.391

marriage is legal before the law and should not be treated differently.

Relating to children born outside of marriage, Constitutional Judge Maria Farida Indrati assumed that in perspective of legislation, a distinction of treatment on children because of certain reasons which is not caused by the actions of the child, can be categorized as discriminatory [Taufiqurrohman Syahuri, 2013, Legislation of Marriage Law in Indonesia Pro-Contra of its Formation until decision of Constitutional Court, Kencana Prenada Media Group Jakarta, p. 199-200]. The provisions has closed any possible civil relationship with their biological father. It is the risk of unregistered marriage or marriage that is not carried out according to the Marriage Act. However, it is not correct that the child must bear the burden caused by the act (marriage) of the parent. If considered as a sanction, the state and religious law do not recognize the concept of children to bear the penalties, as a result of actions done by their parents. The fulfillment of the rights of children born out of marriage, regardless of the marriage legitimacy under the state law, it remain to be obligation of both biological parents.

If the law shows discrimination either directly or indirectly [L.M.Ghandi Lapian, 2012, Legal Discipline to Realize Gender Equality and Justice, Yayasan Pustaka Obor Indonesia, Jakarta, p.57], meaning that the purpose of law should not discriminate, but if the impact is discriminatory, thus that provision also could be deemed discriminatory.

\section{B. Legal Status of Children Outside Marrige In Bali Customary Law.}

In addition to the state law regulating status of children outside marriage, there also customary law and religious law. Thus regulations on children outside the marriage is legal pluralism. Gurffiths defines legal pluralism as a situation where one or more legal systems applied in the same place and time [Rikardo Simarmata, 2013, Legal pluralism and related Issues, Perkumpulan Huma, h.7]. In the case of child born outside marriage, not all regions have the same perspective. According to Selly Falk Moore [Ibid, p. 7-8.] it is because between the government agency and the people, there are a variety of smaller social organizations which also have rules that enforceability may be imposed, for example indigenous peoples in some areas. it is because between the government agency and the people, there are a variety of smaller social organizations which also have rules that enforceability may be imposed, for example indigenous peoples in some areas.

There are areas like Mentawai, Timor, Minahasa, and Ambon assume that pregnant women outside a legitimate marriage is considered normal, the incident is considered normal just like a mother who gave birth in a legitimate marriage [Bushar Muhammad, 2004, Principles of Customary Law, Pradnya Paramita, Jakarta, p.7]. But in other areas, women who give birth outside a legitimate marriage shall be censured hard both the mother and her child. In ancient times, harsh measures of punishment arise such as expelled from the communion and are not recognized as citizens of communion. To avoid the poor future of the woman and her child, then the men will be forced to marry her. If not, the pregnant woman will be married with another man who is available to marry. This marriage is called Tambelan marriage, pseudo-marriage [Ibid p.8.], also called emergency marriage [Tolib Setiadi, 2009, The Essence of Customary Law in Indonesia (In Literary Review) Alfabeta Bandung, p.210]. If no one wants to marry her, in Bali pregnant women can be inbred with a keris, because keris [Keris is a weapon made of iron with a number of indentation and very sharp tip. Keris is used as male symbol (purusa). Keris has intangible power for the owner and believed to bring for luck, safety, magic, and immune for the holder] is a symbol of male (purusa).

Although efforts have been made so that the child born within a legitimate marriage, but the negative feelings and views on the child born cannot be eliminated. That child in Java is called "bastard child", in Bali called bebinjat [Bebinjat comes from the word bibi (other) njat means rude, so bebinjat means a child born by a rude mother or immoral woman], child, while the child recognized by the biological father is called " astra child " [Gde Panetje, 1989, Various notes of Balinese Customary Law, Guna Agung, Denpasar, p. 26].

VE Korn [VE Korn, 1978, Familial Customary Law in Bali, (translated and given notes by I Gede Wayan Pangkat) Denpasar, Board of Legal publication and Documentaton, Faculty of Law and Social Sciences Udayana University, Denpasar, p.9 and 57] has blurred understanding on the child outside marriage by equating the meaning of bebinjat and astra children, whereas I WayanGde Rank distinguish the understanding on astra and bebinjat children. Bebinjat children are those whose unknown biological father. Astra children's biological father is known, but the child is born before the marriage ceremony performed. In general In general, astra child is said as a child of biological father with a higher caste than the child's mother.

The legal position of the child outside of marriage (astra or bebinjat child) based on Raad Kerta jurisprudence of Denpasar, Decree dated June $9^{\text {th }}, 1938$ No.93/Civiel, to give the children born of the "forced" marriage, the inheritance rights of his grandfather from pancar wadu ( father of the child's mother). If someday the child outside marriage is later received recognition from his biological father's family, the child will only recognized as members of the "dadia of his/herfather". [Dadia is a place for praying to the spirit of ancestral father (male lineage)] As long as he/she does not ask for inheritance, purely just to honor the ancestral spirits of his/her father[Gde Panetja, Op Cit, p. 30]. Based on awigawig of indigenous villages studied, as follows:

a) Awig-awig of Pakraman Sesetan Village [Awig-Awig Customary Village of Sesetan District of South Denpasar Denpasar City year 2002], Article 52 paragraph (4) states in case of illegitimate marriage result in the birth of a child, the child is not called bebinjat or astra child, preferably held panyangaskara[panyangaskara ceremony is a kind of marriage ceremony to clean the body and soul of a child born outside marriage] ceremony.

b) Awig-awig of Pakraman Kesiman Village [Awig-Awig of Pakraman village Kesiman District of East Denpasar, Denpasar city year 2010], Article 65 paragraph (2) says 


\section{International Journal of Science and Research (IJSR) \\ ISSN (Online): 2319-7064 \\ Index Copernicus Value (2013): 6.14 | Impact Factor (2015): 6.391}

that if there is a pregnant woman but no man acknowladge it, then the woman should be made a marriage and cleansing ceremonies for herself and the child to be born.

c) Awig-awig of Pakraman Medahan village [Awig-Awig of Pakraman village Medahan District of Blahbatuh Regency of Gianyar, year 2009] Article 55 (2) says that if there was an illegitimate marriage to bear a child, thus in order to avoid the child called babinjat or astra child, it is compulsory to perform pangaskara ceremony.

d) Awig-awig of Panjer Customary Village, Article 70 states that if there was a pregnant women outside marriage [Awig-Awig of Panjer customary village, District of East Denpasar, Denpasar City, year 1988], firstly ask who has done to be responsible for that. If the man has been identified, then it is better to hold a marriage ceremony soon. Article 73 , if it is not possible, then a marriage and cleaning ceremony should be performed. The ceremony is held to avoid the child called as bebinjat child. The purpose is that woman and her child are allowed to pray to Kahyangan Tiga /Pura Kahyangan tiga is a place for praying to God in manifestation as Brahma (creator), Wisnu (preserver), and Ciwa (buster).] temple. The child born could be appointed as the grandson by his grandfather or father of the child's mother.

According to explanation of Indigenous leader Jero Bendesa Adat Panjer [Nyoman Budiana, 54 years old, education S3, works as lecturer and customary leader of Panjer village]:

"it was happen that no body wants to marry a pregnant women. The woman then married to her uncle, that marriage is just aimed to legitimate in religious law, so that the child to be born will not called bebinja child, and allowed to worship at the temple. This marriage is accompanied with agreement, that the woman and the child to be born do not have any legal relationship. Birth certificate of the child remains a child of a mother. After the child is born, he/she will be appointed as a grandchildren by his/her grandfather and, it is already in accordance with awig-awig regulation of Panjer Customary Village".

The Hindu community in Bali upholds the values of the sanctity of (religious) [I Ketut Artadi, 2006, Law In Cultural Perspective, Cultural Approach on Law, Pustaka Bali Post, Denpasar, p. 71], that any disharmony in the governance of life in society has always been "closed" with ceremonies of returning to harmony, and it's more primary. This is performed to respect the laws made according to values adopted and regarded in the society.

Based on Triangular legal concept of Werner Menski [Achmad Ali, 2012, Revealing Legal Theory) and Judicial Theory Including Interpretation of Constitution (legis Prudence), Kencana Prenada Media Group Jakarta, p. 190], there are three primary types of law including the law created by the state, the law created by the community, and the law arising from ethics and values. The three types are plural, Because each type contains other types. In context of legal status of children outside marriage, the three types of law has served well to protect their legal status and social status of children outside marriage. Position of the child outside marriage has managed to harmonize with the state law, religious law and customary law. It is proven normatively in legislation, jurisprudence and awig-awig of indigenous village regulating legal position of the child outside marriage which is limited to her/his mother.

\subsection{Responsibilities To The Children Outside Marriage From Perspective Of Human Rights}

In general, a child has a legal relationship with both parents. This condition does not apply to children outside of marriage who only have a legal relationship with their mother only. What if in the future after the birth, the mother is married to a man who is not the biological father. There are several cases of children outside marriage based on research results:

1. Cases of children outside marriage taken care by his mother (his mother does not marry again), these cases are common, usually after giving birth, a mother does not want to marry again and decides to keep and take care of the child to adults and even older. The child life and education are responsibility of his mother only. Since women are not included as the heirs, the woman is given a plot of land which is enough to stay together. Beyond marriage child is still viewed negatively by the society, so sometimes it is hard to find a soulmate. As experienced by I Butuhan [I Butuhan, 58 years old, unemployed because he was blind since birth, lives in Sesandan village Regency of Tabanan. In terview was held on tuesday April $5^{\text {th }}$ 2016]. But many have a mate too, such as experienced by IB Astra who had male and female children [IB Astra, 60 years old, works as labor in construction, lives in Sesandan village Kabupaten Tabanan, In terview was held on tuesday 5 April 2016]. The responsibility will be taken by the man.

2. The case of child beyond marriage adopted by the woman's father (grandfather), the case is also common, Because her father wanted to protect the future of his children and grandchildren. Protection for the mother because there is a possibility later to marry a good man with the child's biological father or other men. The case in the village of Timpag Gusti Ayu, Sri [Gusti Ayu Sri, 30 years old, works as an entrepreneur, lives in Timpag village Kabupaten Tabanan, interview was held in september 16 2015] Gave birth a baby outside marriage, having mated with a keris. Her child was raised as a child of her father. Sri then married out, and her child becomes responsibility of Sri's father. The same case experienced by Ni Wayan Sriasih [Ni Wayan Sriasih, 23 years old, works as private employee, lives in Meliling village Kabupaten Tabanan], Ni Made Tiwi [Ni Made Tiwi, 30 years old, works as private employee, lives in Sesandan village Kabupaten Tabanan] and IG Ayu Asrini [Gustiayu Asrini, 32 years old, works as private employee, lives in Sesandan village Kabupaten Tabanan]. Different case is experienced by $\mathrm{Ni}$ Nengah Astini [Ni Nengah Astini, 38 years old, works as a trader, lives in Sesandan village Kabupaten Tabanan] after marriage with keris, giving birth a baby outside marriage. A few months later she married the biological father of her child. Kris marriage had to be conducted by Astini on request of her parents. The purpose is to include the child as the Heir of his grandfather. 


\section{International Journal of Science and Research (IJSR) \\ ISSN (Online): 2319-7064}

Index Copernicus Value (2013): 6.14 | Impact Factor (2015): 6.391

3. The case of children outside of marriage which is not adopted by his grandfather, then left out by the mother to marry, and do not have wives and offspring. This case occurred in the village of Banjar Tegal Buleleng. I Putu Wenten Laut, beyond marriage child abandoned by his mother to marry, and was not raised by his mother's father and never get couple, neither wife nor children. According to information from the indigenous leader Jro Mangku Putu Suparta [Jro Mangku Putu Suparta, 65 years old, a priest, Lives in Banjar Tegal Village] and Ni Nyoman Suhartini [Ni Nyoman Suhartini, 62 years old, retired of civil servant, Lives in Banjar Tegal Village.] states that:

""That the deceased has ever been recognized by his biological father, but there is no responsibility at all from the biological father's family until his death. His mother married out and had died. The deceased was cremated insultly (small), Saturday December 12, 2015. The rest of his life was spent in a nursing home. Implementation of cremation ceremony was performed by the mother's family ".

Researchers participated in the ceremony, the pengabenan ceremony was held simply. It had also asked to one of the families of Ni Ketut Kerti [Ni Ketut Kerti, 70 years old, klingsir of family, Lives in Banjar Tegal Village Buleleng], about responsibilities on the cost of the ceremony is from his mother's family voluntarily. Pengabenan ceremony was conducted at the Foundation of Hindus Community (YPUH) [The Foundation of Hindus protection is managed by Jero Mangku Sedana as the chef of The Foundation management, aimed at giving simple implementation of ngabn ceremony] located at Jalan Pulau Kalimantan Kampumg Baru, located on the waterfront where Putu Wenten ashes were dumped in the sea. Although the ceremony was very small and simple, the most important thing for the family is that spirit of Putu Wenten was already consecrated. The next ceremony requires greater expense where the family has not been able to hold. Based on the child's status as a child outside marriage which is not legally appointed, it lead to the child outside marriage does not have inheritance rights in his mother's family.

According to Robert Audi [Majda El-Muhtaj, 2012, Human right in Indonesian Constitution, Kencana Prenada Media Group, Jakarta, p.41.] rights strongly associated with status. Child rights, for example, are the rights attached to the status of a person, where they interact. Differences between inherit rights of children outside marriage and children of legal marriage, are not in accordance with equality principle $[\mathrm{H}$. Muladi, 2009, Human rights:Philosiphy, Conscept and its Implication in Legal and Social Perspective, Refika Aditama, Bandung, p. 278] that every child has equal rights and status. The difference in terms of inheritance rights is included in categorical discrimination, in which there are discriminatory treatment based on social and cultural status. Child protection should remain to be holistic effort to include the child as a human being worth receiving appropriate attention. In this context Abdul Hakim Garuda Nusantara [Majda El Muhtaj, 2013, Dimentions of Human Rights Describing Right of Economy, Social, and Culture. Raja Grafindo Persada, Depok Jakarta, p.228] also found the child not only need to be approached juridically but also economically, socially and culturally.
Criterias of Customary Inheritance law in Bali is associated with legal sense of indigenous peoples in the atmosphere of freedom, obviously the criteria is values of Pancasila and principles contained in the Constitution of 1945 that lead to the human rights values. [Md Pasek Diantha, I Gede Pasek Eka Wisanjaya, 2010, Caste In Legal and Human Right Perspektive, Universitas Udayana Press, p. 132] Based on the theory of the working of Law in the Society by Williem J.Chambliss and Robert B. Seidman [Williem J. Chamblis dan Robert B, Seidman, 1971, Law, Order, and Power, Reading, Mess, Addison-Wesly. p.12.], mechanism of law in the society is influenced by social forces, institutions of law makers and law enforcement agencies. The performance of the human rights regulations also depend on such factors including law makers, community stakeholders, as well as law enforcement [Muladi, 2009, Human rights:Philosiphy, Conscept and its Implication in Legal and Social Perspective, Refika Aditama, Bandung, p. 89].

Based on the theory above the legal position of inheritance rights by the child outside marriage according to Balinese customary law, like that of happened to the deceased is not fair. Therefore, legislators and law enforcement need to make a change in the inheritance rights of children outside of marriage. The child right is not protected because of what his parents done. If it is associated with inheritance rights of women, the female is asuun (one part) and male is ategen (two parts). Part for mother of the deceased is eliminated because his mother was marrying out causes Putu Wenten did not get anything. This applies to children outside of marriage in Bali, because laws and awig-awig has been set up that way. The condition is in accordance with the theory of Legal System by Lawrence M.Friedman [Lawrence M. Friedman, 1969, The Legal System : A Social Science Perspecitive, Russel Sage Foundation, New York, p. 16.]prioritizing legal culture of society. If the law is upheld in the society, the legal culture of lawmakers, judges legal culture and legal culture of society should be in harmony or in one direction with the applicable regulations. The applicable regulations is guaranteed an impartial and fair for humanity.

Based on the description above, rights of beyond marriage children is not protected by the Act and Customary Law of Bali. But jurisprudence has given right of inheritance to children outside of marriage from his mother's father (grandfather), but in fact the child outside of marriage should be adopted beforehand, in order to have a clear legal status. Adoption requires the consent of the other heirs, so that hope to be aopted is very small, because it would harm the legitimate heirs.

Roles of indigenous rulers, leaders is necessary to uphold justice [Soerjono Soeknto, 2001, Customary Law of Indonesia, Rajawali Pers Jakarta, p.155-156] to maintain the harmonization of social relation patterns as the core of social processes. The public will be satisfied with the government if unification of community with traditional elders could be realized. The point is, to synchronize with the development of society. Customary elders should have the character of brave, wise, fair, truthful, sentimental and humane. Elders is law enforcement agent in the broadest sense. He should be 


\section{International Journal of Science and Research (IJSR) \\ ISSN (Online): 2319-7064}

Index Copernicus Value (2013): 6.14 | Impact Factor (2015): 6.391

formator of law, law enforcement, and pioneer of legal developments especially in the field of Customary Law of Inheritance, so that children outside marriage can get the inheritance rights from their parents and grandfather. So the elders are expected to have ability to follow the development of society, maintaining law of local wisdom, discard, remove laws that are not in accordance with the era.

\section{Conclusion}

\subsection{Conclusion}

1) The legal status of children outside of marriage under the Act, Awig-awig of Pakraman and Jurisprudence is limited to his/her mother and father of his/her mother.

2) The responsibility of the woman's family toward the child outside marriage is until his/her death and obliged to perform the pengabenan ceremony. The legal position which is limited to civil relationship with his/her mother is an unfair and discriminatory action.

\subsection{Recommendation}

Fulfillment of rights for both children of legitimate or illegitimate marriage should be the same, in terms of legal status, social status, including the right to inherit, regardless of the marriage legitimacy of their parents. Raad Kerta Jurisprudence of Denpasar may be applied to provide protection of inheritance rights for children outside of marriage.

\section{References}

\section{Book}

[1] Achmad Ali, 2012, Revealing Legal Theory) and Judicial Theory Including Interpretation of Constitution (legis Prudence), Kencana Prenada Media Group Jakarta.

[2] Artadi, I Ketut. 2006, Law In Cultural Perspective, Cultural Approach on Law, Pustaka Bali Post, Denpasar.

[3] Astiti, Tjok Putra. 1994, Infuence of Customary Law and Plannrd Family Program toward changing values of doughter and son in the Community of Bali (Disertation). Postgraduate Program Institut Pertanian Bogor.

[4] Bushar Muhammad, 2004, Principles of Customary Law, Pradnya Paramita, Jakarta.

[5] Darma Putra, I Nyoman. 2007, Balinese Woman of Old Era : Current perspective, Pustaka Larasan, Denpasar Bali.

[6] Diantha, Md Pasek, I Gede Pasek Eka Wisanjaya. 2010, Caste In Legal and Human Right Perspektive, Universitas Udayana Press.

[7] Friedman, Lawrence M. 1969, The Legal System : A Social Science Perspecitive, Russel Sage Foundation, New York.

[8] Ghandi Lapian, L.M. 2012, Legal Discipline to Realize Gender Equality and Justice, Yayasan Pustaka Obor Indonesia, Jakarta.

[9] Jones, E. 1962, Cureent Trends in Legal Research, (Ekspert), Journal of Legal EEducation.
[10] Korn, VE. 1978, Familial Customary Law in Bali, (translated and given notes by I Gede Wayan Pangkat) Denpasar, Board of Legal publication and Documentaton, Faculty of Law and Social Sciences Udayana University, Denpasar.

[11] Majda El-Muhtaj, 2012, Human right in Indonesian Constitution, Kencana Prenada Media Group, Jakarta.

[12] Majda El Muhtaj, 2013, Dimentions of Human Rights Describing Right of Economy, Social, and Culture. Raja Grafindo Persada, Depok Jakarta.

[13] Moleong, Lexy J. 1990, Qualitative Research Methodology, Tarsito Bandung.

[14] Muladi, 2009, Human rights:Philosiphy, Conscept and its Implication in Legal and Social Perspective, Refika Aditama, Bandung.

[15] Panetje, Gde. 1989,Various notes of Balinese Customary Law, Publisher Guna Agung, Denpasar.

[16] Rikardo Simarmata, 2013, Legal pluralism and related Issues, Perkumpulan Huma.

[17] Sadnyini, Ida Ayu. 2015, Women Marriage With Keris In bali In Three Dimension Appaches (jurnal Internasional), IJSEA Internasional Journal of Software Engineering \& Applications Volume 1 Issu7, October 2015.

[18] Soehino, H. 2013, Human Right, Development of Regulation and Implementation of Human Right in Indonesia, BPFE Yogyakarta.

[19] Soerjono Soekanto and Sri Mamuji, 1990, Normative Legal Research :A Short Review, CV, Rajawali, Jakarta.

[20] Soerjono Soekanto, 2001, Customary Law of Indonesia, Rajawali Pers Jakarta,

[21] Sugiono, 2008, Understanding Qualitative Research Equipped with example of Research proposal and Report, Publisher Alpabeta.

[22] Supasti Darmawan, 2005, Empirical Researh Method, without place of publisher.

[23] Taufiqurrohman Syahuri, 2013, Legislation of Marriage Law in Indonesia Pro-Contra of its Formation until decision of Constitutional Court, Kencana Prenada Media Group Jakarta.

[24] Tolib Setiadi, 2009, The Essence of Customary Law in Indonesia (In Literary Review) Alfabeta Bandung.

[25] Williem J. Chamblis dan Robert B, Seidman, 1971, Law, Order, and Power, Reading, Mess, AddisonWesly.

\section{Awig-awig}

[26] Awig-Awig of Panjer customary village, District of East Denpasar, Denpasar City, year 1988.

[27] Awig-Awig Customary Village of Sesetan District of South Denpasar Denpasar City year 2002.

[28] Awig-Awig of Pakraman village Medahan District of Blahbatuh Regency of Gianyar, year 2009.

[29] Awig-Awig of Pakraman village Kesiman District of East Denpasar, Denpasar city year 2010. 